\title{
THE VICTIM HANDLING MODEL OF HUMAN TRAFFICKING THROUGH ECONOMIC INDEPENDENCE
}

\author{
Henny Nuraeny and Tanti Kirana Utami \\ Faculty of Law Universitas Suryakancana \\ E-mail: hennynuraeny28@gmail.com
}

\begin{abstract}
Human Trafficking is a modern trading of human slavery. Human Trafficking is also one of the worst forms of violation of human dignity that results in trauma to the victims. To that end, there should be a comprehensive treatment for victims. The problems that can be studied is whether a model that can be applied in the treatment of victims of trafficking in Cianjur and disseminating technical how models Handling of Victims of Human Trafficking in Cianjur. This study used normative juridical approach and specification of descriptive analysis. The results of this study are alternative models to handle victims of trafficking in Cianjur is a service model based on inter-institutional and economic empowerment through planting camelina sativa with socialization techniques involving local government, private sector, community leaders and students through legal counseling and advocacy.
\end{abstract}

Keywords: human trafficking, the victim handling model, socialization

\begin{abstract}
Abstrak
Perdagangan orang adalah perdagangan modern dari perbudakan manusia. Perdagangan orang juga merupakan salah satu bentuk perlakuan terburuk dari pelanggaran harkat dan martabat manusia yang mengakibatkan trauma bagi para korban. Untuk itu, perlu dilakukan penanganan secara komprehensif bagi korban. Permasalahan yang ditelaah adalah model apakah yang dapat diterapkan dalam penanganan korban perdagangan orang di Kabupaten Cianjur dan bagaimanakah teknis mensosialisasikan model Penanganan Korban Perdagangan Orang (Trafficking) di Kabupaten Cianjur. Penelitian ini menggunakan metode pendekatan yuridis normatif dan spesifikasi penelitian deskriptif analisis. Hasil dari penelitian ini adalah alternative model penanganan korban perdagangan orang yang diterapkan di Kabupaten Cianjur adalah model pelayanan berbasis antar institusi dan pemberdayaan ekonomi masyarakat melalui penanaman camelina sativa dengan teknik sosialisasi melibatkan pemerintah daerah, pihak swasta, tokoh masyarakat dan mahasiswa melalui penyuluhan hukum dan advokasi.
\end{abstract}

Kata kunci: perdagangan orang, model penanganan korban, sosialisasi

\section{Introduction}

Nowadays human trafficking is categorized as a crime toward the development and welfare of society because its scope has extended called as organized crime. Organized crime usually move in a neat formulation, againts any person who obstructs business or their business as competitor. Human trafficking is the same as the form of slavery in the past era.

This type of trafficking was initially located in the larger cities, but the development of information technology and transformation have widely spread into the villages. People of

\footnotetext{
$\Omega$ Funded by DIPA Kopertis IV, Ministry of Research, Technology, and Higher Education, Hibah Bersaing Research Year 2015.
}

trafficker-who has quickly developped as transnational syndicates-are smoothly trapping their prey, but harshly exploiting them with many different ways, so that the victim will be powerless to free themselves. The impact experienced by victims of human trafficking is so various, generally fall into the prostitution ( $\mathrm{Fe}$ male Commercial Sex), the exploitation of labor and others. The perpetrators are generally carried out by agents of the contracting labor with the mode of granting job and either pas-sively (by job advertisements) or actively (directs to people's homes) recruit them who are expecting a job. 
The number of human trafficking victims was processed by KPPPA Year 2011-2013 decreased in the Year 2011 amounted to 221 (two hundred twenty one) persons, in 2012 amounted to 220 (two hundred twenty) persons and in 2013 amounted to 92 (ninety two) persons. Furthermore, the condition of ESA (Sexual Exploitation of Children) and trafficking in Indonesia are: first, the exact number is not known, it is estimated $30 \%$ from the Sexual Workers are children who are victims of ESA (40.000-150.000); second, around 7452 children in the region of Central Java, Yogyakarta and East Java are victims of ESA; third, 14.000 children around Jakarta and West Java are involved in ESA; fourth, many children are involved in ESA illegal (unregistered or outside localization); fifth, youngest age is 10-12 years old, except for those experiencing sexual violence and are victims of pedophile; sixth, spread in all the commercial sex industry, either in town or village; seventh, Customers from all circle, both domestic or international' and eighth, not rarely are victim of trafficking in country and across borders. Generally, the victims suffer physical, physocological, mental and social loss, so that they require assistance and protection equally and humanely.

\section{Problems}

This paper will discuss about: first, The victim handling model of human trafficking which is appropriately applied in Cianjur; and second, technique of socialization of the victim handling model of human trafficking ?

\section{Research Methods}

This study uses normative juridical approach, which is descriptive analysis. Types and sources of data used are primary data are derived from interviews with stakeholders and secondary data as the primary data is legislation, for example; Act of 1945, Criminal Code, Law Number 21 Year 2007 concerning Combating Trafficking in Persons, Law Number 39 Year 1999 concerning Human Rights, which is supported by literaturea and scientific journals.
The technique of collecting and processing data were retrieved from literature data and field data (Integrated Services Center for Women and Children (P2TP2A) and Police). Further qualitative data analysis using the method of triangulation. Triangulation is a model of circular checks, so that the resources obtained are accurate and accountable. The location of this research conducted in Cianjur. Data analysis is the next step to process the results into a report.

\section{Discussion}

\section{The Victim Handling of Human Trafficking}

Indonesia embraces the principle and the concept of Pancasila contained in the preamble of the Constitution of $1945 . .^{1}$ The problems of law enforcement in Indonesia is a way of thinking that is very positivistic and legalistic/perspectives legislation. ${ }^{2}$ Law is the instrument to an established state through the power it has, ${ }^{3}$ then one as the deciding factor in holding power is the norm or law.

One of the fundamental changes after the amendment of the 1945 Constitution in a series of four stages from 1999 to 2002 is an affirmation espoused principles of the law as stated in Article 1 (3) of the 1945 Constitution. ${ }^{4}$ Indonesia as one of the country based on the rule of law upholds human rights, embodied in various provisions related to human rights. One is the legislation of human trafficking. In the context of human rights protection, as human beings, women and children also have the same rights as

1 Abdul Wahid, "Hak Atas Informasi Atau Kebohongan Publik", Jurnal Konstitusi, Vol. 6 No. 3, September 2009, Jakarta: Mahkamah Konstitusi, page 3.

2 Kristian, "Penyelesaian perkara pidana dengan konsep atau pendekatan keadilan restorative (restorative justice) khususnya secara mediasi (mediasi penal) dalam system hukum pidana Indonesia ditinjau dari filsafat hukum", Jurnal Mimbar Justitia, Vol. VI No. 2, July-December 2014, Cianjur: Faculty of Law Universitas Suryakencana, page 458.

3 Dedi Mulyadi dan Rendi Aridhayandi, "Putusan Mahkamah Konstitusi tentang Pemilu Serentak Dihubungkan dengan Pencegahan Korupsi Politik", Jurnal Hukum Mimbar Justitia, Vol. I No. 02, July-December 2015, Cianjur: Faculty of Law Universitas Suryakencana, page 537.

4 Atang Hermawan Usman, "Kesadaran Hukum masyarakat dan Pemerintah sebagai Faktor Tegaknya Negara Hukum di Indonesia”, Jurnal Wawasan Hukum, Vol. 30 No. 1, February 2014, Bandung: Sekolah Tinggi Hukum Bandung, page 26. 
other human beings on earth, namely the right which is understood as the rights attached (inherent) naturally since they were born, and human beings (women and children) can live as a normal human. ${ }^{5}$

The symptoms of society can be a variety of shapes and background. One of the social phenomenon in the form of human rights violations are human trafficking, because it is the prevention of the crime of Human Trafficking should be based on human rights law which aim to create order, justice and prosperity. Efforts to take precautions against a strategic human trafficking socially because it requires criminal policies whose purpose is to lessen crime and meet the demands for social justice. ${ }^{6}$

Law Number 21 Year 2007 concerning Eradication of Criminal Act of Human Trafficking is an effort to provide legal protection either directly or indirectly to the victim and/or potential victims from becoming victims in the future. As an illustration, the author describes the data on cases of trafficking in Cianjur can be seen in the table below:

Table 2. Data of number Trafficking Case be handled by P2TP2A

\begin{tabular}{|c|c|c|}
\hline No. & Year & Number of case \\
\hline 1 & 2009 & 33 \\
\hline 2 & 2010 & 21 \\
\hline 3 & 2011 & 8 \\
\hline 4 & 2012 & 12 \\
\hline 5 & 2013 & 32 \\
\hline 6 & 2014 & 18 \\
\hline 7 & 2015 & 8 \\
\hline Source Data : Central Office of Integrated Services Center \\
for Women and Children (P2TP2A) Cianjur \\
Regency in 2016
\end{tabular}

While, cases archived by Cianjur Police Resort can be seen in the table below:

Table 3. Cases of Trafficking handled by Cianjur Police Resort:

\begin{tabular}{|c|c|c|}
\hline No. & Year & Number of case \\
\hline 1 & 2010 & 8 \\
\hline 2 & 2011 & 2 \\
\hline
\end{tabular}

5 John D passalbessy, "Dampak Tindak Kekerasan terha-dap Perempuan dan Anak serta Solusinya", Jurnal Sasi Vol. 16 No. 3, July-September 2010, Ambon-Maluku: Universitas Pattimura, page 9.

6 Henny Nuraeny, 2011, Kebijakan Hukum Pidana terha-dap Pencegahan Tindak Pidana Perdagangan Orang, Jakarta: Sinar Grafika, page 149.

\begin{tabular}{|l|l|l|}
\hline 3 & 2012 & 1 \\
\hline 4 & 2013 & 1 \\
\hline 5 & 2014 & 3 \\
\hline 6 & 2015 & 1 \\
\hline
\end{tabular}

Source Data: Cianjur Police Resort in 2016.

Based on the data above, human trafficking cases are decreasing due to several factors which are law enforcement, awarness on society about law beside factor of law itself. ${ }^{7}$

Based on perspective of victim, the general factors suffered by victims of trafficking are material and immaterial losses (physic, psychic, economic, and social), which are: first, materiil losses. These losses arise due to the condition of the victim in a state of weak economic terms (poverty), and low levels of education, it will be easier for traffickers to commit fraud, extortion, forgery, debt bondage, from departure to return to his hometown. Second, immaterial losses. More victims suffered these losses, such as physical, psychological, and social loss. Victims are generally very vulnerable to violence because they are in a weak condition (women and children), so that the victims often suffer inhuman treatment, either from traffickers (actor/ brokers/sponsor), company employment, and their employers in the workplace. More immaterial losses suffered by the victim, because it can lead to disability (permanent) as a result of inhuman torture (health problems). In addition, not a few victims who suffered psychological damages such as mental disorders (stress), because disappointment over the treatment that is received in workplace does not match in first time of description that traffickers promised. While the losses are heavily suffered by the victim is social loss, such as exclusion from the home environment because victims return with different condition (pregnant due to rape in the workplace), this is often experienced by victims of trafficking.

Based on several factors and other factors suffered by the victim, the target of criminal law policy which was originally directed to

7 Dewi Asri Yustia, "Penerapan Restorative Justice Terhadap Orang Tua Pelaku Perdagangan Anak dalam Perspektif Sistem Peradilan PIdana Indonesia", Jurnal IImu Hukum LITIGASI, Vol. 14 No. 1, April 2013, Bandung: Universitas Pasundan, page 1853. 
crime as the prevention of crime, shifted to the person (Offender) with the goal of treatment of Offender, and develop to the victim whose targeted to treatment of victims. The treatment towards victims, in accordance with nowadays' development, is in order to abolish the paradigm that criminal law only treats offenders. ${ }^{8}$

Following the case above, the author formulated a model of handling trafficking victims through a humanist approach in order to increase the economic independence as follows: first, Spiritual Awareness. Secondly, Building Motivation. Third, Skills Training Preparation (LifeSkill) as a form of stimulus for creating a business field that can be done to generate income that meets their needs. This can be done by Integrated Services Center for Women and Children (P2TP2A), Department of Population and Civil Registration (Disdukcapil) and NGOs. Fourth, Flocking Assistance through community institutions in order to create a healthy and constructive process of interaction with the community and become an important human resources and is able to contribute in development. It can be corporation with various universities in the form of Community Service Program (KKN) Thematic Posdaya, Integrated Services Center for Women and Children (P2TP2A), the handling of human trafficking. Fifth, providing assistance or advocacy to victims. Sixth, providing information and employment opportunities. Seventh, proposing to the local government regarding to the regulations about local economic empowerment.

Models to handle victims of Human Trafficking has been described above, the authors conclude in the slogan "Model Pelayanan Berbasis Antar Institusi Dan Model Sejahtera Sekeluarga Melalui Pemberdayaan Ekonomi". Model of Prosperous Family is a community empowered through the camelina sativa cultivation. According to state theory, the state has the primary goal in creating prosperity evenly, therefore the type of welfare state with its focus on equali-

\footnotetext{
8 Arief Amarullah, Politik Hukum Pidana Perlindungan Korban Tindak Pidana Perdagangan Orang,Dalam Satya Arinanto \& Ninuk Triyani (Ed), 2009, Memahami Hukum Dari Konstruksi Sampai Implementasi, Jakarta: Raja Grapindo Persada, page 133.
}

zation, the state is required to intervene and play an active role in creating prosperity. ${ }^{9}$

\section{Socialization models to handle victims of traf- ficking in Cianjur}

Models to handle victims of Human Trafficking needs to socialize to society with the aims for people to understand about human trafficking and countermeasures. The implementations, made as formal and informal. Formal socialization was conducted through cooperation with various parties including government, universities or non governmental. Informal socialization was conducted during a meeting with mothers of social gathering, the lecturers at the break, there was a meeting in the community.

Implementation of socialization as follows: first, cooperation with P2TP2A to all Principal and Teacher of Guidance and Counseling in the district of Cianjur (Cianjur North, Central and South Cianjur, Cianjur). Second, Implicated by Tourism Department on abolition workshop of trafficking in persons, sexual exploitation of children and drugs. Third, having implicated by BKBPP in the discussion of child protection activities issues in Cianjur. Fourth, Socialixation in the University Suryakancana both formal and informal. Fifth, supervisor of KKN equipped with pocket book to understand trafficking for dissemination in village. Sixth, Doing dissemination to students of Law Faculty in cooperation with lecturer supervising the subjects related to the problem of human trafficking for example criminal law, human rights law, employment law, HTN, state law, and etc. Seventh, socialization to Meeting of Regional Leaders (MUSPIDA) Cianjur Regency. Eighth, Socialization to society at KKN. Ninth, socialization informally during the social gathering, family gathering, and recitals, seminar at UNSUR.

In socialization handling trafficking victims, there are several obstacles which emerge that is approached to government and society

\footnotetext{
9 Ujang Charda, "Tanggung Jawab Negara Indonesia dalam Perlindungan Hukum Terhadap Tenaga Kerja Anak", Jurnal Wawasan Hukum, Vol. 30 No. 1 February 2014, Bandung: Sekolah tinggi Hukum Bandung, page 17.
} 
and still lack knowledge of participants. In the socialization must consider the moral and ethical.

\section{Conclusion}

Models to handle victims of Human Trafficking which can be applied in Cianjur, namely through the strengthening of capital, such as giving assistance to victims of both stimulant and cash assistance in the form of skills training. Strengthening program is implemented by the Government of Cianjur regency in cooperation with stakeholders, such as budget provision in budget and in partnership with the skills. Technique of socialization of Victims Handling Model of Human Trafficking in Cianjur is in cooperation with local government, related institutions, community leaders and students conducting KKN so as to reach wider community.

\section{References}

Amarullah, Arief. Politik Hukum Pidana Perlindungan Korban Tindak Pidana Perdagangan Orang. In Satya Arinanto \& Ninuk Triyani (Ed). 2009. Memahami Hukum Dari Konstruksi Sampai Implementasi. Jakarta: Raja Grapindo Persada;

Charda, Ujang. "Tanggung Jawab Negara Indonesia Dalam Perlindungan Hukum Terhadap Tenaga Kerja Anak". Jurnal Wawasan Hukum. Vol. 30 No. 1 February 2014. Bandung: Sekolah tinggi Hukum Bandung;

Kristian. "Penyelesaian Perkara Pidana Dengan Konsep atau Pendekatan Keadilan Restoratif (Restorative Justice) Khususnya Se- cara Mediasi (Mediasi Penal) Dalam Sistem Hukum Pidana Indonesia Ditinjau Dari Filsafat Hukum". Jurnal Mimbar Justitia. Vol. VI No. 2. July-December 2014 edition. Cianjur: Faculty of Law Universitas Suryakencana;

Mulyadi, Dedi dan Rendi Aridhayandi. "Putusan Mahkamah Konstitusi tentang Pemilu Serentak Dihubungkan dengan Pencegahan Korupsi Politik". Jurnal Hukum Mimbar Justitia. Vol. I No. 02. July-December 2015 edition. Cianjur: Faculty of Law Universitas Suryakencana;

Nuraeny, Henny. 2011. Kebijakan Hukum Pidana terhadap Pencegahan Tindak Pidana Perdagangan Orang. Jakarta: Sinar Grafika;

Passalbessy, John D. "Dampak Tindak Kekerasan Terhadap Perempuan dan Anak serta Solusinya". Jurnal Sasi Vol. 16 No. 3. JulySeptember 2010 edition. Ambon-Maluku: Universitas Pattimura;

Usman, Atang Hermawan. "Kesadaran Hukum Masyarakat dan Pemerintah sebagai Faktor Tegaknya Negara Hukum di Indonesia". Jurnal Wawasan Hukum. Vol. 30 No. 1. February 2014. Bandung: Sekolah Tinggi Hukum Bandung;

Wahid, Abdul. "Hak Atas Informasi Atau Kebohongan Public". Jurnal Konstitusi. Vol. 6 No. 3. September 2009. Jakarta: Mahkamah Konstitusi;

Yustia, Dewi Asri. "Penerapan Restorative Justice Terhadap Orang Tua Pelaku Perdagangan Anak dalam Perspektif Sistem Peradilan Pidana Indonesia”. Jurnal Ilmu Hukum LITIGASI. Vol. 14 No. 1. April 2013. Bandung: Universitas Pasundan. 